\title{
Neonatal Red Cell Superoxide Dismutase Enzyme Levels: Possible Role as a Cellular Defense Mechanism against Pulmonary Oxygen Toxicity
}

\author{
BEDFORD W. BONTA, ELIZABETH R. GAWRON, AND JOSEPH B. WARSHAW(46) \\ Yale University School of Medicine, Division of Perinatal Medicine, Departments of Pediatrics, Obstetrics, and \\ Gynecology, and Yale-New Haven Hospital, New Haven, Connecticut, USA
}

\begin{abstract}
Summary
Red cell superoxide dismutase (SOD) enzyme activity was determined in 58 cord blood specimens obtained from infants over a range of gestational ages. An inverse relationship between red cell SOD activity and gestational age was demonstrated. Red cell SOD activity showed a progressive fall from $263.1 \pm 30.5$ units/mg non-hemoglobin protein (NHP) in infants of less than 29 weeks of gestation to $168.9 \pm 21.3$ units/mg NHP in infants of more than 36 weeks of gestation $(P<0.05)$. Infants treated for RDS showed an increase in red cell SOD activity which reached significance at 72 hr when compared to cord blood levels from the same population $(P<0.05)$. No similar significant difference could be demonstrated in gestational age-matched control subjects over the same time period. However, initial cord blood SOD enzyme levels were lower in premature infants with RDS (229.5 \pm 30.6 units/mg NHP) than in premature infants without RDS $(264.0 \pm 38.0$ units $/ \mathrm{mg}$ NHP). When infants with RDS were examined for oxygen toxicity and survival, red cell SOD levels were noted to decrease over $\mathbf{2 4} \mathbf{~ h r}$ in four of five infants who died, three of whom developed bronchopulmonary dysplasia. In the surviving infants, red cell SOD levels showed a significant increase by $48 \mathrm{hr}(P<0.05)$. None developed bronchopulmonary dyplasia and all survived.
\end{abstract}

\section{Speculation}

Increases in red cell superoxide dismutase activity in response to hyperoxic stress may prevent toxic effects of $\mathrm{O}_{2}^{-}$radicals and oxygen toxicity to the lung.

Oxygen is fundamental to survival of aerobic systems. However, in excess, molecular oxygen has been associated with toxic tissue effects as noted in bronchopulmonary dysplasia $(4,8,33$, 38 ) and retrolental fibroplasia (22). The complete reduction of 1 molecule of oxygen yields intermediates which include $\mathrm{O}_{2}{ }^{-}$(superoxide radical), $\mathrm{OH} \cdot\left(\right.$ hydroxyl radical), and $\mathrm{H}_{2} \mathrm{O}_{2}(24)$. Fridovich $(12,13,17,18,25,40)$ and others (32) have recently proposed that a major part of oxygen toxicity at the cellular level may be mediated by the superoxide radical. All oxygen-metabolizing cells so far examined have been found to contain enzymes that catalyze the reaction: $\mathrm{O}_{2}{ }^{-}+\mathrm{O}_{2}{ }^{-}+2 \mathrm{H}^{+} \rightarrow \mathrm{H}_{2} \mathrm{O}_{2}+\mathrm{O}_{2}$. These enzymes, which have been characterized as metalloproteins, are designated superoxide dismutases (12).

Mammalian studies have only recently been attempted in an effort to delineate the relationship of SOD enzyme levels and the occurence of pulmonary oxygen toxicity $(3,8,14)$. Decreased levels of lung SOD have been demonstrated in those infants dying from RDS $(4,38)$. Induction of enzyme activity has been observed in rat lungs after exposure to increased oxygen concentrations $(3,8,14)$ and seems to be dependent upon the presence of an unidentified factor in plasma for induction to be demonstrated (3).

The red cell provides an accessible source of human SOD. Although the relationship of SOD to bronchopulmonary dysplasia is not clearly understood, measurement of red cell SOD activity in red cells may reflect a response to intrapulmonary exposure to $\mathrm{O}_{2}{ }^{-}$radicals and provide a mechanism for their removal while the red cell is in close proximity to the alveolar wall. Oxygen induced lung damage has been associated with oxygen-induced hemolysis (44). In the present study, we have (1) compared cord blood levels of red cell SOD over a range of gestational ages and (2) compared the SOD response of premature infants with RDS exposed to oxygen over $72 \mathrm{hr}$ of therapy with gestational age-matched premature infants without RDS over a similar 72-hr period; and (3) evaluated the relationship of red cell SOD enzyme activity over a 72-hr period to the development of pulmonary oxygen toxicity in infants treated for RDS.

\section{METHODS}

Fifty-eight cord blood specimens were obtained for analysis. Gestational age was determined by the method of Dubowitz et al . (10) and by the mother's expected date of confinement. An additional study was performed over a 72-hr period on 22 infants: 11 premature infants with RDS and hyperoxic exposure and 11 premature infants of similar gestational age and birth weight without RDS maintained in room air. Mean birth weight of the non-RDS group was $1619 \mathrm{~g}$. Those with RDS were provided sufficient oxygen $\left(\mathrm{FIO}_{2}\right)$ to keep their $\mathrm{PaO}_{2}$ between $50-70 \mathrm{~mm} \mathrm{Hg}$. Continuous positive airway pressure (CPAP) was used when required $\mathrm{FIO}_{2}$ was greater than 0.60 , whereas mechanical ventilation (volume-cycled) with positive end-expiratory pressure (PEEP) was used when $\mathrm{FIO}_{2}$ of greater than 0.80 was required and/or apnea with hypercarbia $\left(\mathrm{PaCO}_{2}>65\right)$ developed. $\mathrm{FIO}_{2}$ was measured with a Beckman oxygen analyzer and $\mathrm{PaO}_{2}$ was determined in infants with RDS with a Radiometer Copenhagen acid-base blood gas analyzer.

Cord blood and neonatal specimens were anticoagulated with acid-citrate-dextrose and stored at $4^{\circ}$. Preparation of the red cell SOD fraction was performed using a modification of the methods of McCord and Fridovich (26) and Deutsch $(20,21,41,42)$. A $1.0 \times 4 \mathrm{~cm}$ DEAE-cellulose column (DE-52 Whatman Chemical Co.), previously equilibrated with $\mathrm{Na}$ phosphate buffer, $\mathrm{pH} 7.25$, was used to separate hemoglobin from nonhemoglobin protein.

Non-hemoglobin protein was then eluted from the column with $4 \mathrm{ml} 300 \mathrm{mM}$. Na-acetate buffer. The resulting eluent was stored at $-10^{\circ}$ until assayed for SOD enzyme activity.

SOD enzyme activity was determined by its ability to inhibit the autoxidation of colorless epinephrine to colored adrenochrome according to the method of Fridovich et al. (30). This was detected spectrophotometrically using a Gilford kinetic 
spectrophotometer at $480 \mathrm{~nm}$. One unit of SOD enzyme activity was defined as the concentration which inhibited adrenochrome formation by $50 \%$ of control rate. Pure bovine erythrocyte superoxide dismutase (Truett Laboratory, 45) was used as a standard. Hemoglobin contamination of the nonhemoglobin fraction was measured by the standard clinical benzidine method (7). Non-hemoglobin protein in the column eluant was determined by subtracting hemoglobin protein from total protein determined by the biuret reaction (16). Units of SOD activity are expressed per $\mathrm{mg}$ non-hemoglobin protein.

\section{RESULTS}

\section{ASSAY RELIABILITY}

Pure bovine SOD in varying concentrations inhibited autoxidation of epinephrine under assay conditions $(0.3 \mathrm{mM}$ epinephrine, $0.1 \mathrm{mM}$ EDTA, $50 \mathrm{mM}$ Na carbonate buffer, $\mathrm{pH} \mathrm{10.2)}$ corresponding to the work of Fridovich (30). When the reciprocal of percentage of inhibition $\times 10^{2}$ was plotted against the reciprocal of the fractional dilution of the sample, a straight line relationship was obtained (15). Hemoglobin autoxidation of epinephrine in the range present in eluted samples $(0.005-$ $0.040 \mathrm{mg} / \mathrm{ml}$ ) accounted for less than $10 \%$ of total autoxidation of epinephrine. This is acceptable for assay conditions (15). Mean level for non-hemoglobin protein for all samples tested equaled $0.97 \pm 0.13 \mathrm{mg} / \mathrm{ml}$. Range of values on 39 samples tested varied from 0.78 to $1.30 \mathrm{mg} / \mathrm{ml}$ and did not significantly affect calculated SOD results when expressed in units/mg NHP.

\section{CORD RED CELL SUPEROXIDE DISMUTASE ENZYME ACTIVITY}

Cord red cell samples were examined for a relationship between red cell SOD enzyme activity and gestational age. The date indicates an inverse relationship between red cell SOD activity and increasing gestational age (Fig. 1). Independent ttest analysis between groups demonstrated statistical significance for cord blood red cell SOD enzyme activity from samples

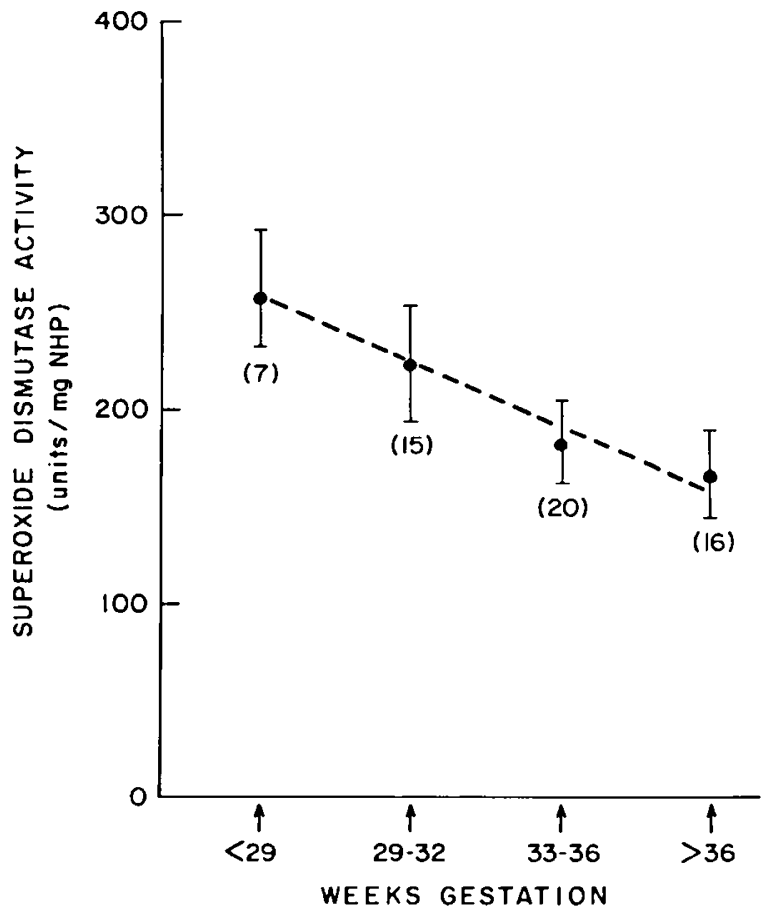

Fig. 1. Cord blood superoxide dismutase enzyme activity as a function of gestational age. Superoxide dismutase activity is expressed as units per $\mathrm{mg}$ non-hemoglobin protein (NHP). Mean and standard error range are shown for each group. Sample size is shown in parentheses. A straight line relationship was obtained by the method of least squares.

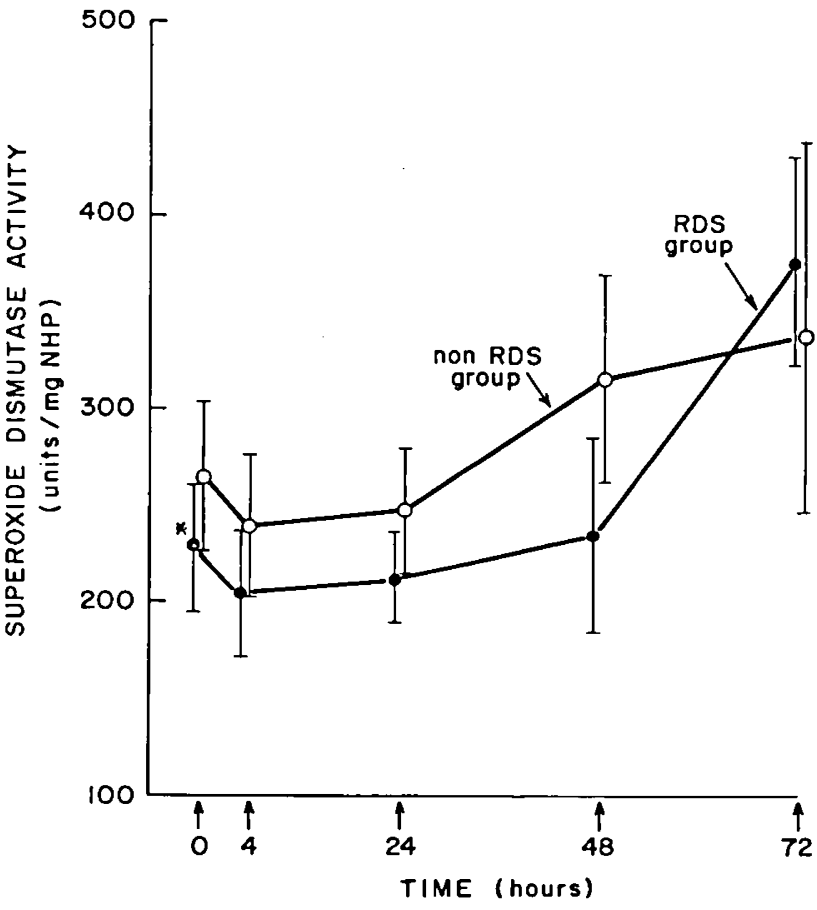

Fig. 2. Superoxide dismutase enzyme activity in red cell samples from infants with and without ideopathic respiratory distress syndrome (RDS) as a function of time postnatally. Mean and standard error are shown for each time period. Zero time refers to cord blood levels. $\bullet-$ : RDS group; $\mathrm{O}-\mathrm{O}$ : non-RDS group. Superoxide dismutase activity is expressed as units per $\mathrm{mg}$ non-hemoglobin protein $(N H P)$.

obtained from infants less than 29 weeks of gestational age versus samples obtained from infants of more than 36 weeks of gestational age $\left(\mathrm{T}_{1}=2.22, P<0.05\right)$.

\section{COMPARISON OF RED CELL SOD ENZYME ACTIVITY IN PREMA- TURES WITH AND WITHOUT RDS}

Eleven infants in each group were included whose cord blood samples had been obtained prior to subsequent samples at 4,24 , 48 , and $72 \mathrm{hr}$. Sample size in each time period varied as some of the infants, particularly those in the RDS, treated group, received packed red cell transfusions, eliminating any further sampling. Although independent $t$-test analysis revealed no significant differences when comparing red cell SOD enzyme levels between groups for each time period (Fig. 2), paired $t$-test analysis for mean SOD levels at different time periods compared to cord blood levels within each group demonstrated statistical significance by $72 \mathrm{hr}$ in the RDS group $\left(\mathrm{T}_{\mathrm{p}}=2.49, P<0.05\right)$. This may be explained by noting that initial mean cord red cell SOD enzyme levels were lower in premature infants with RDS $(229.5 \pm 30.6$ units $/ \mathrm{mg}$ NHP) than levels obtained from the group without RDS $(264.0 \pm 38.0$ units $/ \mathrm{mg} \mathrm{NHP}$, in agreement with a previous report (4).

\section{COMPARISON OF RED CELL SOD ACTIVITY IN RDS GROUP WITH BRONCHOPULMONARY DYSPLASIA AND/OR DEATH VERSUS NO BRONCHOPULMONARY DYSPLASIA AND SURVIVAL}

Table 1 tabulates the results of SOD activity in 11 infants treated for RDS. Bronchopulmonary dysplasia was identified clinically and radiographically in three of five infants who died during therapy. In four of five, not only did red cell SOD levels decline over $24 \mathrm{hr}$, but none survived. All five met criteria for mechanical ventilation with PEEP. In the remaining 6 of 11 who did not develop bronchopulmonary dysplasia or die, an increase in SOD activity was noted (Fig. 3). Three required mechanical ventilation with PEEP whereas the remaining three required only CPAP. Although mean $\mathrm{PaO}_{2}$ over $48 \mathrm{hr}(56.6 \mathrm{~mm} \mathrm{Hg}$ 
Table 1. Red cell superoxide dismutase enzyme activity in respiratory distress syndrome, treated group versus bronchopulmonary dysplasia and survival

\begin{tabular}{|c|c|c|c|c|c|c|c|c|c|c|c|c|c|}
\hline Infant & BW & GA & Birth & $4 \mathrm{hr}$ & $24 \mathrm{hr}$ & $48 \mathrm{hr}$ & $72 \mathrm{hr}$ & Therapy & $\begin{array}{c}\text { Mean } \\
\mathrm{PaO}_{2} \\
(48 \mathrm{hr})\end{array}$ & $\begin{array}{c}\text { Hours } \\
\mathrm{FIO}_{2} \\
>0.40\end{array}$ & BPD & Survival & Died \\
\hline$I$ & 1620 & 32 & 232.5 & & 88.2 & 115.0 & & $\mathrm{MV}+\mathrm{PEEP}$ & 60.0 & 18 & + & - & 8 days \\
\hline 3 & 1670 & 32 & 265.2 & 217.0 & 175.0 & 130.5 & & $\mathrm{MV}+\mathrm{PEEP}$ & 66.0 & 106 & + & - & 5 days \\
\hline 4 & 980 & 26 & 485.6 & 300.0 & 374.0 & & & $\mathrm{MV}+\mathrm{PEEP}$ & 47.0 & 9 & - & - & $36 \mathrm{hr}$ \\
\hline 5 & 850 & 27 & 125.9 & 130.0 & 166.0 & & & $\mathrm{MV}+$ PEEP & 51.0 & 30 & - & - & $30 \mathrm{hr}$ \\
\hline 6 & 1730 & 32 & 147.0 & 133.0 & 250.0 & & 544.5 & $\mathrm{MV}+\mathrm{PEEP}$ & 71.0 & 49 & - & + & \\
\hline 7 & 1235 & 31 & 221.0 & & 246.7 & 152.0 & 343.4 & $\mathrm{MV}+\mathrm{PEEP}$ & 56.5 & 48 & - & + & \\
\hline 8 & 2670 & 36 & 164.2 & & 173.0 & 257.9 & & $\mathrm{MV}+\mathrm{PEEP}$ & 52.5 & 39 & - & + & \\
\hline 9 & 1830 & 32 & 221.0 & & 220.0 & 230.2 & 277.4 & CPAP & 60.0 & 78 & - & + & \\
\hline 10 & 1090 & 31 & 225.0 & & 242.2 & 290.0 & 251.9 & CPAP & 59.0 & 24 & - & + & \\
\hline
\end{tabular}

' Superoxide dismutase activity expressed in units per mg non-hemoglobin protein. BW: birth weight; GA: gestational age; BPD: bronchopulmonary dysplasia; MV: mechanical ventilation; PEEP: positive end-expiratory pressure; CPAP: continuous positive airway pressure.

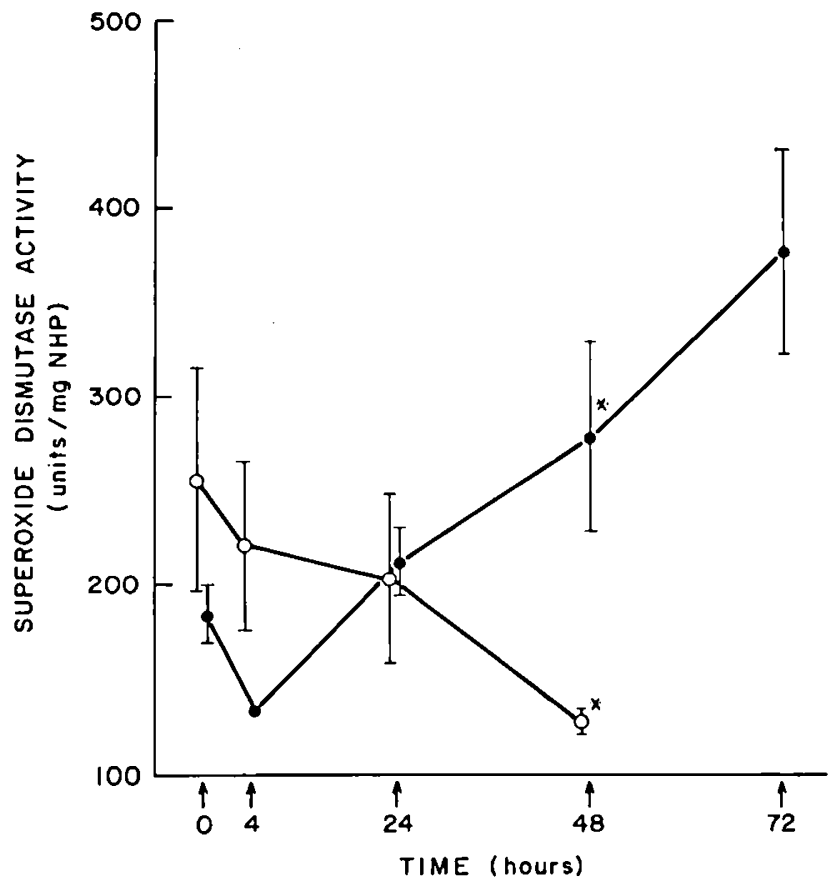

Fig. 3. Superoxide dismutase enzyme activity of infants with ideopathic respiratory distress syndrome with and without bronchopulmonary dysplasia and death as a function of time postnatally. Mean and standard error are shown for each group. Zero time refers to cord blood. $\mathrm{O}-\mathrm{O}$ : nonsurvivors; $\bullet-\bullet$ : survivors. Superoxide dismutase activity is expressed as units per $\mathrm{mg}$ non-hemoglobin protein (NHP).

versus $60.3 \mathrm{~mm} \mathrm{Hg}$ ) and mean duration of $\mathrm{FIO}_{2}$ greater than $0.40(43.4 \mathrm{hr}$ versus $45.0 \mathrm{hr})$ did not differ significantly, comparison of levels between these two subgroups demonstrated a statistically significant difference at $48 \mathrm{hr}\left(\mathrm{T}_{1}=2.98, P<0.05\right)$. No comparison could be made at $72 \mathrm{hr}$ as no values were available in the group with bronchopulmonary dysplasia who died, but a further increase in red cell SOD enzyme activity was noted among five of six infants with values obtained at $72 \mathrm{hr}$ who survived without bronchopulmonary dysplasia.

\section{DISCUSSION}

Multiple assays have been developed to measure SOD enzyme activity from a variety of sources $(1,2,6,9,26,27,31,34,36)$. In indirect assays, $\mathrm{O}_{2}{ }^{-}$is scavenged by an indicator molecule that becomes oxidized or reduced. SOD is detected by its ability to inhibit modification of the indicator scavenger by $\mathrm{O}_{2}{ }^{-}$, in this case by its ability to inhibit oxidation of epinephrine to adrenochrome in the presence of $\mathrm{O}_{2}{ }^{-}$. At elevated $\mathrm{pH}(10.2)$, epinephrine is autoxidized by a complex chain of electron transfers involving the $\mathrm{O}_{2}{ }^{-}$radical (12). Under these conditions, a separate source of $\mathrm{O}_{2}{ }^{-}$is not required and the enzyme can be assayed by its ability to inhibit autoxidation of epinephrine (30). Similarly, hemoglobin can cause both co-oxidation and peroxidation of epinephrine to adrenochrome, the former via the superoxide radical (31). This may be an alternative explanation for the presence of SOD within the red cell to prevent toxic exposure to $\mathrm{O}_{2}{ }^{-}$generated by hemoglobin autoxidation. We do not understand why red cell SOD activity is higher in the younger gestational age premature infants (Fig. 1). However, fetal tissues are exposed to oxygen from conception and the presence of intracellular SOD to prevent toxic exposure to $\mathrm{O}_{2}{ }^{-}$radicals may be required early in gestation. Although $\mathrm{PaO}_{2}$ is constant throughout gestation (20-22 mm Hg) (39), a higher basal SOD level may be necessary to protect immature cell membranes during early gestation with decreasing dependence upon this mechanism as the fetus matures.

The pathophysiology of bronchopulmonary dysplasia has been well established $(5,23,28,29,32,33,35,37,40,43)$. We know that pulmonary complications may occur after only $24 \mathrm{hr}$ of $100 \%$ oxygen exposure. The pathology includes abnormal permeability of pulmonary capillary endothelium, proliferation of pulmonary capillaries, metamorphosis of type II alveolar cells, necrosis of type I alveolar cells, necrosis of type I alveolar cells, changes in mucosal epithelium from columnar to squamous appearance, transudation of fluid and formed elements into alveolar spaces, and patchy atelectasis and hemorrhage, both alveolar and interstitial (40). The protective effect of SOD in preventing such cellular changes has been studied by several investigators. Superoxide dismutase has the ability to protect specifically against at least one means of peroxidative damage, that caused by $\mathrm{O}_{2}{ }^{-}$. Fee and Teitelbaum (11) noted that peroxidative dialuric acid-induced hemolysis in vitamin E-deficient rat red cells was decreased by adding bovine SOD to the red cell 
suspension. SOD was never found to have a protective effect by itself but in the presence of catalase, which prevents abnormal accumulation of $\mathrm{H}_{2} \mathrm{O}_{2}$, protection was demonstrated. The necessary presence of both enzymes to protect against hemolysis where neither can protect alone is further evidence that an intermediate species other than $\mathrm{O}_{2}{ }^{-}$may be exerting the toxic effect. The hydroxyl radical, formed from the substrates of both enzymes by the reaction

$$
\mathrm{H}^{+}+\mathrm{O}_{2}^{-}+\mathrm{H}_{2} \mathrm{O}_{2} \rightarrow \mathrm{O}_{2}+\mathrm{H}_{2} \mathrm{O}+\mathrm{OH}^{\cdot}
$$

may play such a role (19).

Within $2 \mathrm{hr}$ postnatally, an infant's $\mathrm{PaO}_{2}$ is greater than 80 $\mathrm{mm} \mathrm{Hg} \mathrm{(39).} \mathrm{Birth,} \mathrm{therefore,} \mathrm{represents} \mathrm{an} \mathrm{oxygen} \mathrm{challenge.}$ If red cell SOD enzyme induction is possible, an increase in central arterial $\mathrm{PaO}_{2}$ may act as a stimulus to immature red cell in bone marrow to increase intracellular activity of SOD to prevent toxic exposure to $\mathrm{O}_{2}{ }^{-}$. However, if changes in activity depend upon changes in arterial $\mathrm{PaO}_{2}$, only small increases in red cell SOD would be anticipated in babies with RDS, since the aim of therapy is to keep central $\mathrm{PaO}_{2}$ in a therapeutic range (50-70 mm Hg). However, the range of $\mathrm{PaO}_{2}$ noted in several of the 11 infants studied indicates that such close control was not always possible. Measurement of red cell SOD may provide an indirect measure of intracellular response to alveolar hyperoxic stress. Data from our study indicates that both normal neonates and neonates with RDS exposed to hyperoxia demonstrated increased red cell SOD activity, especially after $72 \mathrm{hr}$ of oxygen exposure (Fig. 2). The mechanism for these changes is not clear. Since mature red cells are devoid of protein-synthesizing capability (2), increases in SOD must reflect activation of SOD in red cells, synthesis of new enzyme by reticulocytes, or release into the circulation of a new population of red cells containing high SOD activity.

\section{CONCLUSION}

Our observation that prematures developing RDS tend to have lower red cell SOD enzyme activity than those who do not develop the disorder (Fig. 2) suggests that oxidative injury to alveolar membranes may have a causal relationship to RDS itself. Furthermore, the neonate's ability to respond to hyperoxia by increasing intracellular activity of SOD, both in red cells and pulmonary parenchyma, may well determine whether or not significant oxygen toxicity may develop. Our data (Fig. 3) demonstrate that increasing activity of red cell SOD correlates with absence of bronchopulmonary dysplasia and survival whereas failure to respond to hyperoxia and mechanical ventilation is associated with bronchopulmonary dysplasia and/or death. By increasing intracellular SOD activity in response to hyperoxic stress, toxic exposure to $\mathrm{O}_{2}{ }^{-}$radicals may be prevented and integrity of the cell membrane preserved.

\section{REFERENCES AND NOTES}

1. Aleman, V., and Handler, P.: Dihydroorotate dehydrogenase. I. General properties. J. Biol. Chem., 242: 4087(1967).

2. Asada, K., Urano, M., and Takahashi, M.: Subcellular location of superoxide dismutase in spinach leaves and preparation and properties of crystalline spinach superoxide dismutase. Eur. J. Biochem., 36: 257 (1973).

3. Autor, A. P., Frank, L., and Roberts, R. J.: Developmental characteristics of pulmonary superoxide dismutase: Relationship to idiopathic respiratory distress syndrome. Pediat. Res., 10:154 (1976).

4. Autor, A. P., and Roberts, R. J.: Superoxide dismutase activity and isoenzymes in the human fetal and adult lung. Fed. Proc., 33: 1505 (1974)

5. Avery, M. E.: What is bronchopulmonary dysplasia? Human Pathol., 1: 321 (1970).

6. Behar, D., Czapski, G., Rabani, J., Dorfman, L. M., and Schwartz, H.A.: The acid dissociation constant and decay kinetics of the perhydroxyl radical. J. Phys. Chem., 74: 3209 (1970).

7. Cartwright, G. E.: Diagnostic Laboratory Hematology, 4th Ed. (Grune \& Stratton, New York, 1970).

8. Crapo, J. D., and Tierney, D. F.: Superoxide dismutase and pulmonary oxygen toxicity, Amer. J. Physiol., 225: 1404 (1974).

9. Curnuttee, J. T., and Babior, B. M.: The effect of bacteria and serum on superoxide production by granulocytes, J. Clin. Invest., 43: 1662 (1974)

10. Dubowitz, L. M. S., Dubowitz, V., and Goldberg, C.: Clinical assessment of gestational age in the newborn infant, J. Pediat., 77: 1 (1970).

11. Fee, J. A., and Teitelbaum, H. D.: Evidence that superoxide dismutase plays a role in protecting red blood cells against peroxidative hemolysis. Biochem. Biophys. Res. Commun., 49: 150 (1972).

12. Fridovich, I.: Superoxide dismutase. Advan. Enzyme, 41: 35 (1974).

13. Fridovich, I.: Superoxide radical and superoxide dismutase. Acc. Chem. Res. 5: $321(1972)$.

14. Frank, L., Autor, A. P., and Roberts, R. J.: Effect of hyperoxia on superoxide dismutase (SOD) activity in neonatal animals. Pediat. Res., 10: 460 (1976).

15. Gawron, E. R.: Neonatal red cell superoxide dismutase levels: Activity assay of the enzyme protective against oxygen toxicity (Yale University School of Medicine, New Haven, Conn., 1975).

16. Gornall, A. G., Bardawill, C. J., and David, M. M.: Determination of serum proteins by means of the biuret reaction, J. Biol. Chem., 177: 751 (1949).

17. Gregory, D. E. M., and Fridovich, I.: Induction of superoxide dismutase by molecular oxygen, J. Bacteriol., 144: 543 (1973).

18. Gregory, E. M., and Fridovich, I.: Oxygen toxicity and the superoxide dismutase, J. Bacteriol., 114: 1193 (1973).

19. Haber, F., and Weiss, J.: The hydroxyl radical and oxygen toxicity. Proc. R. Soc. London, A147: 332 (1974).

20. Hartz, J. W., and Deutsch, H. F.: Subunit structure of human superoxide dismutase. J. Biol. Chem., 247: 7043 (1972)

21. Hartz, J., and Deutsch, H. F.: Preparation and physiocochemical properties of human erythrocuprein. J. Biol. Chem., 244: 4565 (1969).

22. James, L. S., and Lanman, J. T., Ed.: History of oxygen therapy and retrolental fibroplasia. Pediatrics, 57: 591 (1976).

23. Kann, H. E., Mengel, C. E., Smith, W. W., and Horton, B. D.: Oxygen toxicity and vitamin E. Aerospace Med., 35: 840 (1964).

24. Lehninger, A.: Biochemistry, p. 391 (Worth Publishers, Inc., New York, 1970).

25. McCord, J. M., Keele, B., and Fridovich, I.: An enzyme-based theory of obligate anaerobiosis: The physiological function of superoxide dismutase, Proc. Natl. Acad. Sci. U. S. A., 68: 1024 (1971)

26. McCord, J. M., and Fridovich, I.: Superoxide dismutase-An enzymic function for erythrocuprein (hemocuprein). J. Biol. Chem., 244: 6049 (1969).

27. McDonagh, A. F.: The role of singlet oxygen in bilirubin photooxidation Biochem. Biophys. Res. Commun., 44: 1306 (1971)

28. Mengel, C. E., Kann, H. E., Smith, W. W., and Horton, B. D.: Effects of in vivo hyperoxia on erythrocytes. I. Hemolysis in mice exposed to hyperbaric oxygenation. Proc. Soc. Exp. Biol. Med., 116: 259 (1964).

29. Mikity, V. G., and Taber, P.: Complications in the treatment of RDS: Bronchopulmonary dysplasia, oxygen toxicity, and the Wilson-Mikity syndrome. Pediat. Clin. North Amer., 20: 419 (1973).

30. Misra, H. P., and Fridovich, I.: The role of superoxide dismutase. J. Biol. Chem., 247: 3170 (1972).

31. Misra, H. P., and Fridovich, I.: The generation of superoxide radical during the autoxidation of hemoglobin. J. Biol. Chem., 247: 6960 (1972).

32. National Heart and Lung Institute, Division of Lung Diseases Pamphlet Report of Workshop on Pulmonary Oxygen Toxicity, Bethesda, Md., February 5-6, 1973.

33. Northway, W. H., Rosen, R. C., and Porter, D. Y.: Pulmonary disease following respirator therapy of hyaline membrane disease. New Engl. J. Med., 276: 357 (1967).

34. Patriarca, P., Cramer, R., Moncalvo, S., Rossi, F., and Romeo, D.: Enzymatic basis of metabolic stimulation in leucocytes during phagocytosis: The role of activated NADPH oxidase. Arch. Biochem. Biophys., 145: 255 (1971).

35. Philip, G. S.: Oxygen plus pressure plus time: Etiology of bronchopulmonary dysplasia. Pediatrics, 55: 44 (1975).

36. Rajagopalon, K. V., Fridovich, I., and Handler, P.: Hepatic aldehyde oxidase. I. Purification and properties. J. Biol. Chem., 237: 922 (1962).

37. Reynolds, E. O. R., and Taghizadeh, A.: Improved prognosis of infants mechanically ventilated for hyaline membrane disease. Arch. Dis. Childhood, 49: 505 (1974).

38. Roberts, R., Frank, L., and Autor, A.: Superoxide dismutase: An enzyme of maturation-Relationship of IRDS. Pediat-Res., 9: 136 (1975).

39. Rudolph, A. M.: Congential Diseases of the Heart, p. 24 (Year Book Medical Publishers, Inc., Chicago, 1974).

40. Saltzman, H. A., and Fridovich, I.: Oxygen toxicity-Introduction to a protective enzyme: superoxide dismutase. Circulation, 49: 921 (1973).

41. Stansell, M. J., and Deutsch, H.: Levels of catalase and erythrocuprein in human erythrocytes. Clin. Chem. Acta, 14: 598 (1966).

42. Stansell, M. J., and Deutsch, H. F.: Preparation of crystalline erythrocuprein and catalase from human erythrocytes. J. Biol. Chem., 240: 4200 (1965)

43. Stern, L.: The use and misuse of oxygen in the newborn. Pediat Clin. N. Amer., 20: 447 (1973).

44. Taylor, D. W.: Effect of tocopherols, methylene blue and glutathione on the manifestations of oxygen poisoning in vitamin E-deficient rats, J. Physiol. 140: 37 (1958).

45. Dallas, Texas.

46. Requests for reprints should be addressed to: J. B. Warshaw, M.D., Yale University School of Medicine, Department of Pediatrics, Obstetrics and Gynecology and Yale-New Haven Hospital, New Haven, Conn. (USA).

47. Received for publication August 6, 1976.

48. Accepted for publication October 27,1976 